\author{
В. Бредіхіна, \\ кандидат юридичних наук, доцент, \\ доцент кафедри екологічного права \\ Національного юридичного університету імені Ярослава Мудрого
}

\title{
ДЕЯКІ ТЕОРЕТИЧНІ АСПЕКТИ ОБМЕЖЕННЯ ЕКОЛОГІЧНИХ ПРАВ ГРОМАДЯН В УМОВАХ РЕАЛІЗАЦІЇ КОНЦЕПЦІЇ СТАЛОГО РОЗВИТКУ
}

В умовах глобального надмірного споживання природних ресурсів, порушення екологічного балансу на планеті перехід людства до сталого розвитку ставить концептуально нові вимоги до визначення місця і ролі людини в навколишньому природному середовищі, задоволення екологічних інтересів сучасного та майбутніх поколінь. Водночас виявляється надзвичайно актуальним забезпечення екологічної рівноваги та безпеки на планеті, збереження іiі ресурсів та охорони довкілля. У цьому зв'язку на сучасному етапі розвитку суспільних екологічних відносин законодавство і право України приділяє особливу увагу закріпленню еколого-правового статусу людини i громадянина у суспільстві та державі. Основним Законом нашої країни проголошено принцип пріоритету прав і свобод людини порівняно з державними та іншими інтересами. Так, у ст. 3 Конституції України закріплено, що людина, іiі життя й здоров'я, честь i гідність, недоторканість і безпека визнаються в Україні найвищою соціальною цінністю. Хоча екологічні права прямо й не віднесені до найвищих соціальних цінностей, вони вважаються основою конституційного закріплення екологічної функції держави, а забезпечення їх реалізації визначено обов'язком останньої, що, своєю чергою, формує зміст і спрямованість сучасної державної екологічної політики.

Водночас Основними засадами (стратегією) державної екологічної політики на період до 2030 р., затвердженими Законом України від 28 лютого 2019 р., визнано першопричинами екологічних проблем України (серед інших) низький рівень розуміння в суспільстві пріоритетів збереження довкілля та переваг збалансованого (сталого) розвитку, незадовільний рівень дотримання природоохоронного законодавства та екологічних прав і обов'язків громадян [1]. Зазначене призвело до того, що економічний розвиток держави протягом тривалого часу супроводжувався і зараз продовжує здійснюватися шляхом незбалансованої та нераціональної експлуатації природних ресурсів, утрати елементів біологічного різноманіття, що затримує, а іноді зовсім унеможливлює досягнення сталого розвитку нашого суспільства. Отже, серед основних напрямів реалізації державної екологічної політики на сучасному етапі окремо виділяються запровадження екосистемного підходу до всіх напрямів соціально-економічного розвитку України, впровадження збалансованого природокористування і збереження та відновлення природних екосистем. Тому до стратегічних цілей, зокрема, віднесено формування в суспільстві екологічних цінностей і засад сталого споживання та виробництва, забезпечення збалансованого розвитку природно-ресурсного потенціалу України.

Проблеми забезпечення екологічних прав, установлення меж їх реалізації з урахуванням концепції сталого розвитку були й $€$ предметом 
дослідження багатьох вітчизняних та зарубіжних науковців. Зазначеним питанням присвячено, зокрема, фундаментальні наукові праці таких українських учених, як В.I. Андрейцев, Г.І. Балюк, А.П. Гетьман, М.В. Краснова, Н.Р. Малишева, Ю.С. Шемшученко, С.М. Кравченко, Н.Р. Кобецька, Г.В. Анісімова та ін. Серед зарубіжних дослідників проблем забезпечення екологічних прав та обов'язків людини i громадянина варто особливо виокремити роботи M.M. Бринчука, M.I. Васильєвої, Т.І. Макарової, С.А. Балашенка та ін. Указаними вченими всебічно досліджено сутність, гарантії та особливості здійснення екологічних прав, проблеми ï захисту, правові питання дотримання екологічних обов'язків. Утім, проблеми правомірного обмеження таких прав, на жаль, не були достатньою мірою висвітлено в еколого-правовій літературі.

Метою даної статті є аналіз правомірних обмежень екологічних прав громадян у контексті реалізації концепції сталого розвитку, вивчення ролі таких обмежень як регуляторів суспільних відносин у сфері природокористування та одного із засобів збереження природно-ресурсного потенціалу нашої країни. Поставлена мета зумовлює вирішення таких завдань: уточнення поняття та визначення сутності обмеження екологічних прав; аналіз та здійснення класифікації видів та форм обмежень; характеристика підстав для обмежень екологічних прав у контексті раціонального використання та збереження природних ресурсів.

Характерною рисою екологічного права, як відомо, є його моральна зумовленість, яка дає змогу за допомогою правових норм здійснювати формування нової людини 3 екологічно спрямованим світоглядом і високою еколого-правовою культурою, виховувати екологічну правосвідомість суспільства, дбайливе ставлення до природних ресурсів та навколишнього середовища у цілому.

Розглядаючи еволюцію розвитку екологічного права, фахівці-правники часто звертаються до положень екологічної етики та філософії, де можна спостерігати існування та ідеологічне «протистояння» двох основних філософських підходів до правового регулювання екологічних суспільних відносин: антропоцентричного (гуманістичного) та (еко-) біоцентричного. В основі антропоцентричного підходу лежить благополуччя та процвітання людини як найвищої цінності у сфері взаємин суспільства і природи, а законодавство та наука покликані захищати життєво важливі (матеріальні, економічні, ресурсні, фізичні, духовні та ін.) інтереси людини від різних зростаючих загроз у природно-техногенній і соціально-економічній сферах життя. Із цих позицій людина, іiі життя й здоров'я стають у центрі механізму правового регулювання охорони та захисту, екологічної безпеки, гарантій реалізаціï суб'єктивних прав, а на державу покладається ціла низка зобов'язань перед людиною зі створення умов для iii «екологічного комфорту» [2, с. 14].

Натомість біоцентричний (екоцентричний) підхід виходить із залежності людини від законів природи і грунтується на уявленні про об'єктивне існування єдиної системи, у рамках якої всі живі організми взаємодіють між собою i 3 навколишнім природним середовищем. У межах цього світоглядного підходу людина є лише одним із представників живих істот, що існують на Землі [3, с. 31-33; 4, с. 47-48]. Прихильники цього підходу вважають, що він найбільш об'єктивно відображає сутність законів природи та їхній вплив на сучасний розвиток суспільства у його взаємозв'язку із середовищем, що його оточує.

Слід відзначити, що останнім часом у філософсько-правовому розумінні місця людини у природі відбуваються концептуальні зрушення від антропоцентризму в бік екоцентризму, який ставить людину в один ряд з усім живим на планеті, або об’єднання зазначених підходів. На думку вчених, у сучасному світі вже немає окремо «людини» i «природи»: людина екологізована, при- 
рода соціалізована [5, с. 77]. Одним із проявів цього процесу $€$ виникнення такого соціально-політичного руху, як енвайронменталізм, який відображає усвідомлення світовою спільнотою проблеми обмеженості природних ресурсів та занепокоєність впливом антропогенного споживання та діяльності на довкілля. Як доречно зазначає Г.І. Балюк, після конференції ООН із навколишнього середовища та розвитку (Ріо-де-Жанейро, 1992 р.) енвайронменталізм розглядається як ідея об'єднання зусиль усіх країн світу та діячів у галузях економіки, політики, техніки, науки, культури, освіти і права для збереження довкілля як природного оточення людини. На думку вченої, саме енвайронменталізм як новітня ідеологія $є$ однією з глобальних парадигм сучасної науки, що спирається на засади сталого розвитку [6, с. 12]. На цій основі на теренах філософії права формується новий напрям - екософія права, що пропонує формувати нову екологічну людину - особистість, відповідальну за стан довкілля [7, с. 104, 107].

На нашу думку, названі концептуальні підходи у цілому є об'єктивно існуючими чинниками взаємодії Людини і Природи. Людина має бути у центрі правової уваги передусім з тих позицій, що вона є основним суб'єктом споживання природних ресурсів для задоволення своїх потреб, а ї̈ діяльність часто слугує причиною забруднення довкілля, втручання в екологічні системи та процеси i, як наслідок, порушення екологічного балансу на планеті. Превалювання в правовому регулюванні екологічних відносин лише одного з підходів (тільки антропоцентричного або суто екоцентричного) може призвести, на нашу думку, або до споживацького знищення природного середовища та його ресурсів заради блага людини, що призведе до глобальної екологічної катастрофи, або, навпаки, до цілковитого нехтування природними правами, свободами та законними інтересами людини як члена суспільства.
У цьому зв'язку варто погодитися з думкою М.В. Краснової, яка пропонує розглядати екологічні права та обов'язки громадян не тільки з традиційних позицій - як систему юридичних можливостей фізичних осіб задовольняти існуючі потреби, а покласти в основу цього комплексного поняття види, форми і способи взаємодії людини та громадянина із навколишнім природним середовищем як місцем і умовою свого існування, наповнити його засадами зобов'язального характеру у значенні посилення відповідальності людини за наслідки будь-якої своєї діяльності, здатної справляти небезпечний вплив на довкілля [8, с. 44-45].

У цьому контексті екологічні права, особливо ті, що реалізуються у сфері природокористування, незважаючи на іх безперечну цінність у демократичному суспільстві, не можуть бути в усіх випадках безмежними і абсолютними. Як зазначають П.М. Рабінович та I.M. Панкевич, обмеженість (небезмежність, конечність) будь-якого права - це його органічна, іманентна, тобто внутрішньо притаманна йому властивість, адже абсолютно безмежних прав у суспільстві в принципі існувати не може [9, с. 38]. Зокрема, реалізація екологічних прав завжди тісно переплітається з відповідальністю людини за ту ймовірну шкоду, яка може бути завдана, наприклад, довкіллю i його ресурсам, окремим природним об’єктам, зокрема в процесі природокористування та внаслідок необмеженого споживання природних благ.

Iз загальнотеоретичних позицій обмеження прав людини - це допустиме міжнародним або внутрішньодержавним правом утручання в права і свободи людини, яке відповідає вимогам законності, необхідності, доцільності і співрозмірності цілі, яка переслідується таким втручанням. В юридичній літературі наводиться багато інтерпретацій стосовно визначення обмеження прав людини. Так, наприклад, О.В. Малько, розглядаючи природу та сутність правових обмежень, визначає їх як уста- 
новлені рамки, у межах яких суб'єкти повинні діяти [10, с. 91]. П.М. Рабінович та I.M. Панкевич розділяють поняття обмеження (як установлення меж) та обмежування прав людини, розуміючи під першим сукупність усіх явищ, які окреслюють зміст та обсяг прав людини, а під другим - діяльність компетентних державних органів з установлення меж (обмежень) щодо здійснення прав людини [9, с. 42]. О.Ф. Черданцев стверджує, що обмеження слід визначати як особливі випадки, коли певні права та свободи зберігаються, але обмежується їх реалізація на визначеній території, у певний відрізок часу або стосовно до конкретного кола суб'єктів [11, с. 369]. На думку Л. Васечко, обмеження прав людини - це звуження їх обсягу, а також чинники, що унеможливлюють або ускладнюють реалізацію особою прав та свобод [12, с. 5]. А.В. Басов, досліджуючи поняття «обмеження» як юридичної категорії, наводить іхні основні ознаки: 1) обмеження являють собою певні юридичні та фактичні наслідки у вигляді «незручних» умов для здійснення правових інтересів відповідних суб'єктів (фізичних та юридичних осіб), права і свободи яких обмежуються, за одночасного задоволення «правових інтересів» суб'єкта владних повноважень, що запровадив такі обмеження, або інтересів третьої сторони, що зацікавлена у запроваджені таких обмежень; 2) обмеження завжди являють собою зменшення «вільної» (дозволеної нормами права) поведінки (дій) [13, с. 30-31].

Слід також звернути увагу на дискусії, що точаться в юридичній літературі з приводу співвідношення понять «правові обмеження» та «обмеження права». Так, деякі представники цивілістичної науки під правовим обмеженням розуміють сукупність елементів правового регулювання, спрямованих на встановлення рамок (меж) дозволеної поведінки суб'єктів, що окреслюють сферу, всередині якої особа може вільно реалізувати свою правоздатність за наявності певних юридичних фактів
[14, с. 110-111]. Інші ж уважають, що обмеження права не можна відносити поряд із заборонами та обов'язками до правових обмежень, оскільки останні $€$ засобами, за допомогою яких відбувається обмеження права [15, с. 71]. В.В. Носік, досліджуючи межі здійснення права власності на землю, під час визначення суті правового обмеження та обмеження права зазначає, що ці категорії співвідносяться як загальне й окреме. Учений визнає, що правові обмеження не зводяться лише до тих норм, які закріплені у законі, а є більш широким поняттям, яке включає у себе передусім загальні принципи права, на основі яких базується забезпечена законом свобода поведінки особи, 3 урахуванням яких у законодавстві допускається вибір дозволених чи заборонених дій суб’єктів [16, с. 144].

На нашу думку, поняття правового обмеження в екологічному праві можна розглядати в широкому та вузькому сенсі. У широкому розумінні ця категорія охоплює всі елементи правового регулювання (у тому числі й обмеження прав), що спрямовані на впорядкування суспільних екологічних відносин шляхом установлення меж дозволеної поведінки суб'єктів у сфері використання природних ресурсів та впливу на довкілля. У цьому сенсі правові обмеження базуються як на нормах законодавства, так i на принципах екологічного права, адміністративних актах, договорах, судових рішеннях. У вузькому розумінні правові обмеження $є$ інструментами, за допомогою яких здійснюється обмеження права, звуження обсягу варіантів можливої дозволеної поведінки на етапі його реалізації заради задоволення інших більш значимих відповідно до ситуації (часто суспільних) інтересів.

Для того щоб обмеження прав громадян виконували свої праворегулюючі функції та досягали встановленої законодавством мети, їх слід відрізняти від порушення прав. В юридичній літературі наводяться їх основні відмінності. Так, якщо обмеження прав людини, як 
зазначалося, - це звуження їх обсягу, а також чинники, що унеможливлюють або ускладнюють реалізацію особою прав та свобод, то порушення прав це протиправне завдання шкоди правам, свободам і законним інтересам особи, групі або невизначеному колу осіб. Окрім того, обмеження прав можуть установлюватися законодавчо, а порушення - ні; порушення прав завжди є протиправними, обмеження ні; обмеження прав людини можуть сприяти забезпеченню більш значущих за змістом або за колом осіб інтересів, порушення, як правило, спрямовані на задоволення приватних інтересів; обмеження дуже часто встановлюються 3 метою попередження порушення прав людини [12, с. 5-6].

Отже, на основі аналізу зазначених теоретико-правових позицій учених доходимо висновку, що права і свободи людини не можна розглядати як абсолютні, бо людина є частиною суспільства та діє в системі суспільних зв'язків, а отже, у системі встановлених цим суспільством меж та правил. Право як один із регуляторів суспільних відносин завжди виступає офіційним мірилом діючої свободи людини, іiі нормою, указником меж належної та можливої поведінки, мірою соціальної відповідальності. Такі його інструменти, як заборони та обмеження, слід уважати об'єктивно необхідними елементами (методами) правового регулювання суспільних відносин. Тому будемо розглядати обмеження екологічних прав як звуження їх обсягу в процесі реалізації з метою задоволення відповідних об'єктивних суспільних інтересів.

Для вирішення поставлених завдань нашої статті необхідно також визначитися 3 можливими критеріями обмеження екологічних прав громадян, ix законністю та обгрунтованістю. У загальному вигляді метою обмеження прав і свобод людини, як правило, $€$ охорона основних загальновизнаних суспільних цінностей: життя, здоров'я, свободи, гідності, забезпечення національної безпеки, суспільного порядку тощо. Прикладом для формулювання критеріїв правомірних обмежень державою індивідуальних прав і свобод $€$ міжнародне законодавство. Так, відповідно до Загальної декларації прав людини 1948 р. (ст. 29 п. 2) під час здійснення своїх прав і свобод кожна людина повинна зазнавати тільки таких обмежень, які встановлені законом виключно з метою забезпечення належного визнання і поваги прав та свобод інших і забезпечення справедливих вимог моралі, громадського порядку й загального добробуту в демократичному суспільстві [17]. Реалізуючи цей підхід, у ст. ст. 8-11, 18 Європейської конвенції про захист прав людини і основоположних свобод 1950 р. визначено фактори правомірного обмеження прав людини. Зокрема, право на повагу до свого приватного і сімейного життя, до свого житла і кореспонденції, закріплене у ст. 8 Конвенції, на яку часто спираються позивачі до Європейського суду з прав людини з метою захисту порушених екологічних прав, може бути обмежене шляхом втручання органів державної влади, яке здійснюється згідно із законом і є необхідним у демократичному суспільстві в інтересах національної та громадської безпеки чи економічного добробуту країни, для запобігання заворушенням чи злочинам, для захисту здоров'я чи моралі або для захисту прав і свобод інших осіб [18].

Таким чином, правомірне обмеження прав людини варто вважати певним компромісом у правових відносинах держави та особи, за допомогою якого досягається розумний баланс між інтересами окремих осіб, суспільства і держави у важливих сферах суспільного життя, зокрема в екологічній.

У зв'язку з викладеним не можна оминути увагою такі категорії, як «екологічний інтерес», суспільні або «публічні екологічні інтереси», які можуть бути як правовстановлюючими, так і правообмежувальними факторами, стояти в основі правомірних обмежень у сфері природокористування та реалізації екологічних та інших прав. Про- 
блеми забезпечення публічних інтересів в екологічному праві, дослідження сутності та змісту поняття «екологічний інтерес» були неодноразово предметом наукових міркувань та теоретичних розробок учених, як фахівців з екологічного, так і конституційного права, економічної теорії, державного управління, філософії права тощо. Зазначеним питанням, зокрема, були присвячені роботи В.К. Попова, М.I. Васильевої, Е.В. Гірусова, В.І. Андрейцева, Г.І. Балюк, А.П. Гетьмана, Г.В. Анісімової, І.П. Андрушко та ін.

Ураховуючи та узагальнюючи численні напрацювання стосовно екологічних інтересів, виділимо основні положення, що, на нашу думку, є важливими для даного дослідження в рамках проблематики обмеження екологічних прав заради збереження природних ресурсів та досягнення екологічної рівноваги на шляху до сталого розвитку.

Отже, екологічний інтерес - це особливого роду ставлення визначених суб'єктів до екологічних потреб та інших екологічних умов життя, що забезпечують їм нормальну життєдіяльність і рівновагу в навколишньому природному середовищі [19, с. 12]. Розрізняють екологічні інтереси, що притаманні окремим громадянам (фізичним особам), юридичним особам, певним соціальним групам, організаціям, суспільству, державі, світовій спільноті. Відповідно, це дає підстави розділити зазначені інтереси на приватні (особисті), публічні (суспільні, державні) та глобальні (міжнародні). Такі інтереси не завжди збігаються, а інколи стоять на протилежних позиціях або ж не кореспондують один одному. На відміну від прав особи інтереси не завжди корелюють з обов'язком для інших осіб [20, с. 32], тому важливо досягти оптимального співвідношення задоволення приватних i публічних екологічних інтересів у сфері природокористування 3 пріоритетом останніх, оскільки публічні інтереси є офіційно визнаними, законними, гарантовані державою й захищаються у разі необ- хідності. До того ж без задоволення публічних інтересів не може йтися про задоволення й гарантування приватних екологічних інтересів [21, с. 502].

Публічний інтерес розглядається як визнаний державою і забезпечений правом інтерес соціальної спільноти, задоволення якого є умовою і гарантією ї існування та розвитку. Публічність екологічного інтересу - це якість, що визначається одночасно двома факторами: його суспільним (загальнозначимим) характером та державною підтримкою, визнанням та гарантованістю [22, с. 19]. Так, сучасні публічні екологічні інтереси полягають у збереженні природних ресурсів та відновленні природних екосистем, здатності цих ресурсів задовольняти потреби як сьогоднішнього, так і прийдешніх поколінь; збереженні та сталому розвитку природно-ресурсного потенціалу території України й ї окремих регіонів; упровадженні сталого, екологічно збалансованого природокористування та забезпеченні на його основі ефективного економічного зростання; забезпеченні рівноправного доступу суб'єктів екологічних відносин до природних ресурсів як основі життєдіяльності теперішнього і майбутніх поколінь; зменшенні негативного впливу на довкілля, зумовленого споживацькою системою виробництва; подоланні ресурсної залежності нашої країни від інших держав тощо.

Для реалізації екологічних інтересів (особливо публічних) виникає необхідність здійснення сукупності певних заходів із боку держави: правових, організаційних, технічних, економічних, превентивних та у процесі забезпечення законності й екологічного правопорядку. Задоволення публічних екологічних інтересів може бути обмежувальним чинником під час здійснення суб'єктами екологічних відносин своїх прав. Право породжує обов'язок і може бути обмежене інтересами суспільства. Це має значення під час визначення меж реалізації екологічних та інших прав і задоволення майнових та немайнових інтересів громадян. 
Філософсько-моральним підгрунтям для встановлення таких правових обмежень, як правило, виступає так званий принцип екологічної доцільності або екологічний імператив, який розповсюджуються на будь-яку екологічно значиму діяльність для збереження природно-ресурсного потенціалу, видового різноманіття, захисту навколишнього природного середовища від надмірного забруднення як безумовних пріоритетів і встановлює межу допустимої активності людини у взаєминах із природою, яку вона не має права переступати за жодних обставин.

Правові обмеження, що передбачені у земельному, водному, лісовому, гірничому, фауністичному, флористичному, природно-заповідному законодавстві, мають свої особливості залежно від природного ресурсу, що використовується, i виду впливу на довкілля. Вони виражаються, зокрема, в обгрунтованому звуженні обсягу відповідних правових можливостей природокористувачів, у формах вимог, лімітів, нормативів, правил, прямих заборон, обов'язків природокористувачів, у встановленні спеціального порядку реалізації їніх суб'єктивних прав, призупиненні діяльності, що порушує екологічні вимоги, запровадженні юридичних санкцій тощо. Існування цих обмежень зумовлене необхідністю збереження суспільно значущих цінностей, що лежать в основі публічних екологічних інтересів.

Аналіз чинного екологічного законодавства дає підстави виділити такі права у сфері екологічних відносин, що можуть бути обмежені заради збереження природних ресурсів та окремих екосистем на шляху до сталого розвитку: право на здійснення загального та спеціального використання природних ресурсів; право на вільний доступ до екологічної інформації та вільне отримання, використання, поширення та зберігання такої інформаціі; право власності на природні ресурси та комплекси; право користування (у т. ч. оренди) природним об’єктом тощо. Конкретні особливості обмеження зазначених прав плануємо висвітлити в наступних публікаціях.

Таким чином, правові обмеження виступають як засіб превентивного правового впливу на поведінку носіїв екологічних прав, спрямованого на захист загального суспільного інтересу - збереження довкілля та його природних ресурсів заради сталого розвитку нашого суспільства та держави. Правомірні обмеження деяких екологічних прав, особливо пов'язаних 3 природокористуванням, сприяють установленню певного екологічного правопорядку у відповідних суспільних відносинах шляхом досягнення рівноваги між інтересами держави, суспільства, юридичних і фізичних осіб у процесі задоволення їхніх матеріальних, майнових, економічних, соціальних та екологічних потреб. Убачається, що обмеження екологічних прав можуть бути встановлені за різними критеріями та причинами, але, як правило, мають на меті забезпечення балансу між економічними, екологічними та соціальними інтересами суспільства. У кінцевому підсумку правомірне обмеження екологічних та інших прав людини і громадянина може сприяти досягненню гармонійного сталого розвитку, де людина не тільки наділена встановленими і гарантованими правовими можливостями, а й свідомо несе відповідальність за збереження довкілля та його природних ресурсів на благо теперішнього і прийдешніх поколінь.

Статтю присвячено визначенню та дослідженню теоретичних засад правомірного обмеження екологічних прав громадян в умовах реалізації концепціi сталого розвитку. Сталий розвиток, як відомо, означає такий розвиток суспільства, який забезпечує задоволення потреб нинішнього покоління без завдання шкоди для можливостей майбутніх поколінь задовольняти свої потреби. Тому сьогодні серед актуальних завдань проголошуються забезпечен- 
ня екологічної безпеки та рівноваги на планеті, збереження основних природних ресурсів та екосистем, шо забезпечують життедіяльність людини, охорона навколищнього природного середовища.

Визнається, щзо тривала незбалансована та нераціональна експлуатація природних ресурсів призводить до погіршення економічного потенціалу нашої країни, ставить iï у ресурсну залежність від інших держав. Отже, у сучасних реаліях важливим $є$ формування в суспільстві екологічних цінностей та переваг. У изоому зв'язку досліджуються філософсько-правові засади розвитку екологічного права, еволючія формування еколого-правового статусу людини у сфері взаємин ї з природним оточенням. На основі цьоого доводиться, що, маючи певні правові можливості у сфері природокористування у вигляді суб'єктивних екологічних прав, людина одночасно має бути відповідальною за наслідки будь-якої своєї діяльності, що може впливати на довкілля.

У статті проаналізовано поняття обмежень прав людини та громадянина, правових обмежень та ї співвідношення. На основі аналізу теоретико-правових позицій учених наводиться поняття правового обмеження в екологічному праві в широкому та вузькому розумінні. Досліджуються критерії обмежень екологічних прав громадян. Зокрема, опрацьовуються такі теоретичні категорії, як «екологічний інтерес», "публічні інтереси в екологічному праві», які можуть стояти в основі правомірних обмежень екологічних прав.

Деталізуються форми обмежень екологічних прав та особливості їх застосування залежно від виду природного ресурсу, що використовується, та ступеню впливу на довкілля.

Ключові слова: екологічні права, правові обмеження, обмеження екологічних прав громадян, природні ресурси, публічні екологічні інтереси.
Bredikhina V. Some theoretical aspects of environmental rights limitation of citizens in conditions of implementation of the concept of sustainable development

The article is devoted to the definition and study of the theoretical principles of the lawful restriction of environmental rights of citizens in the implementation of sustainable development concept. Sustainable development is known to mean the development of a society that meets the needs of the current generation without harming the opportunities for future generations to meet their needs. Therefore, today the provision of environmental safety and balance on the planet, the preservation of basic natural resources and ecosystems that ensure human life, environmental protection are proclaimed among the urgent tasks.

It is acknowledged that a continued unbalanced and irrational exploitation of natural resources leads to the deterioration of the economic potential of our country, and makes it resource dependent on other states. Thus, it is important to form environmental values and benefits in society in modern realities. In this regard, the philosophical and legal foundations of the development of environmental law, the evolution of the ecological and legal status formation of man in the field of its relationship with the natural environment are studied. On this basis, it is argued that having certain legal opportunities in the field of nature management in the form of subjective environmental rights, is also supposed to be responsible for the consequences of any of their activities that may affect the environment.

The article analyzes the concepts of restrictions of human and civil rights, legal restrictions and their relationship. Based on the analysis of theoretical and legal positions of scientists, the concept of legal restriction in environmental law is given in a broad and narrow sense. Criteria for restricting the environmental rights of citizens are studied. In particular, such theoretical 
categories as ecological interest, public interests in ecological law, which may be the basis of lawful restrictions on environmental rights, are studied.

Forms of restrictions of environmental rights and features of their application depending on the type of natural resource used and the degree of impact on the environment are detailed.

Key words: environmental rights, legal restrictions, restrictions of environmental rights of citizens, natural resources, public environmental interests.

\section{Література}

1. Про Основні засади (стратегію) державної екологічної політики України на період до 2030 року : Закон України від 28.02.2019 № 2697-VIII. Голос України. 2019. 30 березня (№ 62).

2. Гетьман А.П. Правові засади безпеки людини в навколишньому природному середовищі. Забезпечення прав в аграрних, земельних, екологічних та природоресурсних відносинах : зб. матеріалів Четвертого зібрання фахівиів споріднених кафедр, м. Одеса, 6-9 червня 2019 р. / відп. ред. д.ю.н., дои. Т.Є. Харитонова, к.ю.н., дои. Х.А. Григор'єва. Одеса : Гельветика, 2019. С. 13-16.

3. Краснова Ю.А. Право екологічнӧ̈ безпеки України: теоретичні аспекти : монографія / за заг. ред. В.М. Ермоленка. Київ : НУБіП України, 2017. 589 с.

4. Краснова М.В. Науково-методологічні питання еволюиї екологічного права. Актуальні проблеми соціального права. Еволющія правового регулювання аграрних, земельних та екологічних відносин : мат. міжнар. наук.-практ. конферениії, м. Львів, 18 листопада 2016 р. / за заг. ред. П.Д. Пилипенка. Львів, 2016. 314 с.

5. Степаненко А.В. Еколого-економічні стратегії в системі забезпечення екологічної безпеки. Наука і наукознавство. 2014. № 4. С. 77-89.

6. Балюк Г.I. Світоглядні та еколого-правові засади взаємодіі людини $і$ природи. Екологічне право України. 2017. № $1-2$. C. $8-13$.

7. Шефель С.В. Екософія права: антропологічний контекст. Вісник Національного університету «Юридична академія України імені Ярослава Мудрого». 2013. № 1(15). С. 101-109.

8. Краснова М.В. Сучасні науково-методологічні проблеми екологічних прав та обов'язків громадян. Еколого-правовии статус людини $і$ громадянина: ретроспективний та перспективний погляди : зб. матеріалів міжнародної науково-практичної конферениії, м. Київ, 31 травня 2019 р. / за заг. ред. М.В. Краснової, Т.О. Коваленко. Чернівиі : Кондратьєв А.В., 2019. С. 42-47.

9. Рабінович П.М., Панкевич I.M. Здійснення прав людини: проблеми обмежування : монографія. Львів : Астрон, 2001. 108 с

10. Малько А.В. Стимулы и ограничения в праве : монография. Москва : Юристъ, 2004. $250 \mathrm{c}$.

11. Черданиев А.Ф. Толкование права и договора : учебное пособие. Москва : Юнити-Дана, 2003. 381 с

12. Васечко Л. Обмеження прав людини в умовах глобалізації: проблеми теорії $і$ практики. Юридична Україна. 2013. № 1. С. 4-8.

13. Басов А.В. Поняття "обмеження» як юридична категорія: теоретичний аспект. Адміністративне право $i$ проиес. 2013. № 1(3). C. 27-33.

14. Камышанский В.П. Право собственности: предель и ограничения : монография. Москва : ЮНИТИ-ДАНА ; Закон и право, 2000. $303 \mathrm{c}$.

15. Безсмертна Н.В. Зәійснення громадянами права власності : дис. ... канд. юрид. наук. Київ, 2001. 213 с.

16. Носік В.В. Межі здійснення права власності на землю: теорія $і$ практика. Ученые записки Таврического национального университета им. В.И. Вернадского. Серия «Юридические науки». 2012. T. 25(64). № 1. C. 141-150.

17. Загальна декларація прав людини 1948 р. Офіційний вісник України. 2008. № 93. Cm. 3103 .

18. Конвенція про захист прав людини $i$ основоположних свобод, ратиф. Законом України від 17.07.1997 № 475/97-BP. URL : https: / / zakon.rada.gov.ua/laws / show/995_004 (дата звернення: 02.06.2020).

19. Попов В.К. Понятие правового обеспечения реализации экологических интересов. Харьков : Укр. ордена Тр. Крас. Знамени юрид. акад., 1991. 41 с.

20. Андрейцев В.І. Право екологічної безпеки : навчальний та науково-практичний посібник. Київ : Знання-Прес, 2002. 332 с.

21. Aнісімова Г.В. Теоретичні засади розвитку екологічного законодавства в контексті природно-правової доктрини : монографія. Харків : Право, 2019. 672 с.

22. Васильева М.И. Публичные интересы в экологическом праве: теория и практика правового регулирования : автореф. дис. ... д-ра юрид. наук. Москва, 2003. 44 с. 